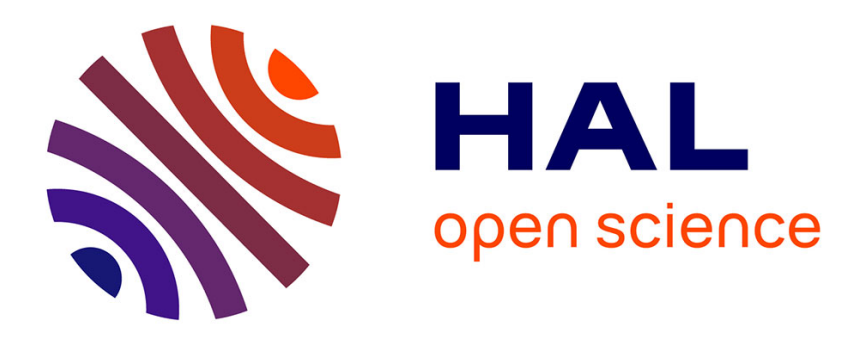

\title{
Challenges of the final stages of the ADV eradication program
}

Maurice Pensaert, Robert Morrison

\section{To cite this version:}

Maurice Pensaert, Robert Morrison. Challenges of the final stages of the ADV eradication program. Veterinary Research, 2000, 31 (1), pp.141-145. 10.1051/vetres:2000061 . hal-00902645

\section{HAL Id: hal-00902645 \\ https://hal.science/hal-00902645}

Submitted on 1 Jan 2000

HAL is a multi-disciplinary open access archive for the deposit and dissemination of scientific research documents, whether they are published or not. The documents may come from teaching and research institutions in France or abroad, or from public or private research centers.
L'archive ouverte pluridisciplinaire HAL, est destinée au dépôt et à la diffusion de documents scientifiques de niveau recherche, publiés ou non, émanant des établissements d'enseignement et de recherche français ou étrangers, des laboratoires publics ou privés. 


\title{
Review article
}

\section{Challenges of the final stages of the ADV eradication program}

\author{
Maurice PENSAERT ${ }^{\mathrm{a} *}$, Robert B. MORRISON ${ }^{\mathrm{b}}$ \\ ${ }^{a}$ Laboratory of Veterinary Virology, Faculty of Veterinary Medicine, University of Gent, \\ Salisburylaan 133, 9820 Merelbeke, Belgium \\ bepartment of Clinical and Population Sciences, College of Veterinary Medicine, \\ University of Minnesota, 1988 Fitch Avenue, St Paul, MN 55108, USA
}

\begin{abstract}
The authors were chairpersons in the session on epidemiology and control of Aujeszky's disease (AD). In this document, they focus on several issues, such as vaccination, compliance and surveillance, which influence the eradication programs. Also, some research topics which may need attention in the future are indicated. The main conclusion is that eradication programs for AD virus have made good progress in different parts of the world and that we have the knowledge and tools to do the job. It must be realized, however, that setbacks can occur. As prevalence declines, susceptibility increases and producers may let their guard down so that the virus may spread again in susceptible areas.
\end{abstract}

\section{Aujeszky's disease / eradication / vaccination / surveillance}

Résumé - Problèmes à surmonter au cours des étapes finales du programme d'éradication du virus de la maladie d'Aujeszky. Les auteurs étaient présidents de la session sur l'épidémiologie et le contrôle de la maladie d'Aujeszky. Dans ce document, ils font le point sur plusieurs problèmes, tels que la vaccination, le respect des réglementations et la surveillance, qui peuvent avoir de l'influence sur les programmes d'éradication. Quelques sujets de recherche, qui pourraient retenir l'attention dans le futur, sont également indiqués. La principale conclusion est que les programmes d'éradication du virus de la maladie d'Aujeszky ont fait beaucoup de progrès dans différentes parties du monde et que nous avons les moyens de les exécuter. Cependant, des échecs peuvent survenir. Alors que la prévalence diminue, la sensibilité augmente ; la vigilance des producteurs peut baisser entraînant à nouveau la propagation du virus dans les zones sensibles.

maladie d'Aujeszky / éradication / vaccination / surveillance

* Correspondence and reprints

Tel.: (32) 926473 65; fax: (32) 926474 95; e-mail: maurice.pensaert@ rug.ac.be 
Table of contents

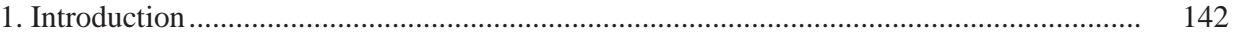

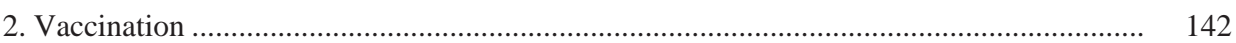

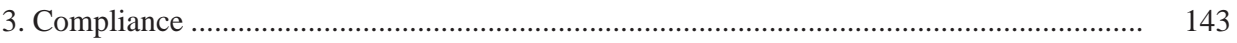

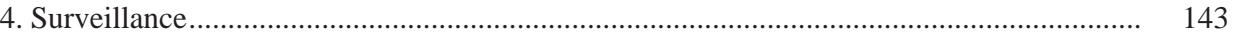

5. Research needs

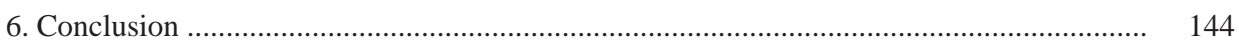

\section{INTRODUCTION}

After reviewing the state of knowledge on the epidemiology and control of Aujeszky's disease virus (ADV), two important conclusions may be made. Firstly, it is clear that we have the knowledge and tools to eliminate the virus from individual herds. Dr. J. Torrison (unpublished results) reviewed the methods that have been successfully employed and Stegeman [5] presented an analysis of the costs for each program. Strategically applied vaccination in conjunction with carefully timed test and removal was the least costly. Secondly, it is essential to eradicate the virus on an area basis, not individual herd basis. The likelihood of re-infection and consequent costs are sufficiently high so that eliminating the virus from an individual herd without considering the risk of area spread is not a wise decision.

Several issues remain that, once answered, will still influence the eradication program. These can be broadly categorized as vaccination, compliance and surveillance.

\section{VACCINATION}

We are fortunate to have highly effective vaccines with accompanying differential serologic tests. These vaccines have played a critically important role in the eradication program. While vaccinated pigs may still become infected, laboratory and field experiences indicate that vaccinated herds will have a significantly lower incidence of new infection, to the point that the prevalence of infected swine will gradually decline to $0 \%$ in the majority of infected herds. This observation reflects a combination of a higher minimum virus dose needed for non-infected pigs, lower viral excretion for fewer days by newly infected pigs and probably a lower incidence of reactivation. Van Nes et al. [7] concluded that a vaccine applied at the regional level could have this same effect: a gradual reduction in wild virus to the point of eventual elimination.

There is little debate that modified live virus (MLV) ADV vaccines are more effective than inactivated vaccines and therefore preferred from a purely efficacy perspective. However, live viral vaccines are susceptible to contamination with adventicious agents and some countries are electing to use inactivated vaccines. Experience from France, as described by Auvigne [1], indicates that inactivated vaccines used in the breeding herd are still effective enough to permit the success of the eradication program.

It is crucial that vaccinations be carried out in a correct and disciplined way on a herd level as well as on an area basis. Poorly vaccinated or non-vaccinated subpopulations play a major role in allowing reinfections to occur particularly in densely swine populated areas where frequent transport of animals between farms occurs. Such populations will jeopardize the success of the program.

The question involving vaccination is when should a herd, region or country withdraw vaccination. The decision is strictly financial; if there was no cost for 
vaccinating, we would continue ad infinitum. There are, however, costs that include the vaccine, its administration, stress on the pig with possible repercussions, slightly less accurate serologic tests, and potentially export limitations. Among European countries, this last cost may outweigh all others many fold and is the driving force to withdraw vaccines as soon as possible. De Koeijer and Stegeman [2] explained a model that they have been using to explore this issue. The model indicates that in the northern part of the Netherlands which has a low pig density, the reproduction ratio between herds $(\mathrm{Rh})$ would remain below 1 and thus major outbreaks would not be expected if vaccination is stopped in finishing pigs while it is continued, however, in breeding animals.

Vaccine withdrawal should be made on a case by case basis, carefully weighing the cost of ongoing vaccines versus the cost of negative consequences.

\section{COMPLIANCE}

As an eradication program proceeds, there will be varying levels of commitment among producers. Laggards will exist in every region and their herds will represent sources of virus that may potentially reinfect the entire region. Westergaard [9] discussed whether such individuals should be handled with a carrot or stick. Should the remaining infected herds be bought out and if so, who pays - the government, other producers, neighbouring regions? Furthermore, what is the appropriate role of the government - we need their guidance in program design, oversight and ensuring compliance; but should we rely totally or even partially on government funding? These issues will be addressed country and region-specific, no doubt.

At any rate, it has become clear from experiences in different countries (for example Sweden, Germany, ...) that vaccination accompanied by culling is, even though more costly, definitely very efficient in rapidly freeing a region of $\mathrm{ADV}$.

\section{SURVEILLANCE}

A key element of an eradication program is surveillance. Throughout the program, infected herds need to be detected as soon as possible so that further spread can be prevented and the virus can be eliminated from the herd. Early in an eradication program, average prevalence will be higher making it easier to detect infected herds. Therefore, sample size is commonly set at $95 \%$ confidence of detecting varying prevalence. Taft (USA) [6] and Zanardi et al. (Italy) [10] described their programs where detection levels were set between 10 and $80 \%$, depending on the situation. As the eradication program continues, prevalence of infected herds will decline and on the average, prevalence within infected herds may be lower. Therefore, sample sizes may increase in order to detect the virus in these herds.

The most cost effective detection level will vary with the stage of the eradication program. Also, we should remember that breeding and finishing are really quite separate sampling units. Finishing is transient and breeding is a better herd indicator. After eradication, surveillance should be conducted regularly in high risk locations.

As Ohlinger et al. [3] described, on occasions, only one serum sample may test positive in a sample of pigs, this being referred to as a single reactor. Single reactors are either true positive or false positive. Unfortunately, we cannot tell which it is after a first test. Considering the source of the sample will improve the predictive value.

A sample is more likely to be a false positive if it is detected in a herd that has a low risk of infection and has no recent history of ADV infection. False positive reactors are to be expected when using a test that is less than $100 \%$ specific. For example, if the test is $99.999 \%$ specific, we will expect to 
have $1 / 1000$ false positive reactions or 100 for every 10000 samples. The proportion of single reactors that are false positives will increase as the eradication program continues.

A sample is a true positive if it comes from an infected pig. If the reactor is from a herd with a history of ADV or in a high risk area, the probability that the pig is infected with ADV is considerably higher. The incidence of true positive reactors will decrease as the eradication program reaches its final stages. We often question how a single positive pig can exist in a herd considering that ADV is infectious. But every infected herd will have a single reactor pig at the beginning of an outbreak and at the end. Because the probability of transmission from an individual infected pig is not always $100 \%$, we can expect to detect an occasional herd with a single infected pig. This could be the first pig in the herd to be infected and further transmission has not occurred (yet?) or it could be the last infected pig in a herd.

We cannot determine whether a reactor is a false positive or a true positive when the serologic history of the herd is lacking and, therefore, all reactors require confirmation and potentially follow-up.

\section{RESEARCH NEEDS}

Do we need more research? More money could mean better diagnostics. For example, PCR has been developed over the last 10 years and was used by Weigel et al. [8] to detect latent ADV in cats and rodents that were residents in ADV infected herds. Other potential developments could include more effective vaccines (to prevent latency? to prevent infection?) and better epidemiologic information (airborne, reactivation with shedding incidence, antivirals). Selhorst et al. [4] used innovative modeling techniques to gain new insight on the spread of ADV within the wild boar population in eastern Germany. But, had we chosen to wait for more knowledge and better tools before starting eradication, we believe we would have prolonged the time to achieve eradication. We believe we have enough information and sufficient tools now to eradicate ADV cost effectively. While we would appreciate better tools and knowledge, we believe research resources are better spent elsewhere.

\section{CONCLUSION}

A clear message from this symposium was that eradication is proceeding in many countries around the world. Several countries have already succeeded (England, Denmark, Sweden) and have remained free. Many countries have made remarkable progress (for example France, Germany, the Netherlands, USA). But setbacks will occur. The state of Minnesota was discussed (Torrison, unpublished results) where the industry has been experiencing a resurgence of ADV over the last 6 months. Speculation is that producers in an endemic area of the state decreased vaccination pressure as a result of difficult market conditions. Coupled with appropriate weather conditions and incorrect handling procedures at slaughter, ADV may have been given the opportunity to infect 150 new herds. The importance of this example is that as prevalence declines, producers may let their guard down. But the opposite needs to happen. As prevalence declines, susceptibility increases. If the virus does get the opportunity to spread, it will spread with vengeance in a susceptible area. An area must keep its guard up until the last infected herd has been detected and the virus has been eliminated.

We have the knowledge and tools to eradicate $\mathrm{ADV}$. We require only the organization and will. Countries and regions within countries are in various stages of eradication programs. This presents us with the opportunity to learn from each other's trials. We must watch successes and failures and document both. Symposia of this type provide a valuable means of 
exchanging experiences so that we can accomplish the goal in the most expeditious manner.

\section{REFERENCES}

[1] Auvigne V. et al., Risk factors of new Aujeszky's disease virus infection in swine herds in Brittany (France), 3rd International Symposium on PRRS and Aujeszky's disease, Ploufragan, France, 2124 June 1999, Vet. Res. 31 (2000) 146-147.

[2] De Koeijer A., Stegeman A., Terminating Aujeszky vaccination in the Netherlands?, 3rd International Symposium on PRRS and Aujeszky's disease, Ploufragan, France, 21-24 June 1999, Vet. Res. 31 (2000) 160-161.

[3] Ohlinger V.F., Pesch S., Hense I., Non-vaccinated subpopulations play a major role in reinfections during eradication programs based on regular vaccination against Aujeszky'disease virus, 3rd International Symposium on PRRS and Aujeszky's disease, Ploufragan, France, 21-24 June 1999, Vet. Res. 31 (2000) 147-148.

[4] Selhorst T., Müller T., Staubach C., Spatial-temporal dynamics of Pseudorabies virus infections in a wild boar population, 3rd International Symposium on PRRS and Aujeszky's disease, Ploufragan, France, 21-24 June 1999, Vet. Res. 31 (2000) 149.

[5] Stegeman A., Effectiveness and costs of different strategies to eradicate Aujeszky's disease virus, 3rd International Symposium on PRRS and
Aujeszky's disease, Ploufragan, France, 21-24 June 1999, Vet. Res. 31 (2000) 158-159.

[6] Taft A.C., The eradication of Aujeszky's disease in the United States, 3rd International Symposium on PRRS and Aujeszky's disease, Ploufragan, France, 21-24 June 1999, Vet. Res. 31 (2000) 157-158.

[7] Van Nes A., De Jong M.C.M., Verheijden J.H.M., Modelling pseudorabies virus infection supports eradication, 3rd International Symposium on PRRS and Aujeszky's disease, Ploufragan, France, 21-24 June 1999, Vet. Res. 31 (2000) 149-150.

[8] Weigel R.M., Hahn E.C., Paszkiet B., Scherba G., Aujeszky's disease Virus (ADV) in mammalian wildlife on swine farms in Illinois (USA): Potential for transmission to non-infected herds, 3rd International Symposium on PRRS and Aujeszky's disease, Ploufragan, France, 21-24 June 1999, Vet. Res. 31 (2000) 148-149.

[9] Westergaard J.M., Aujeszky's disease: the position of the European Commission and regulation perspectives, 3rd International Symposium on PRRS and Aujeszky's disease, Ploufragan, France, 21-24 June 1999, Vet. Res. 31 (2000) 159-160.

[10] Zanardi G., Tamba M., Macchi C., Alborali L., Guadagnini P., Evaluation of italian Aujeszky's disease control programme in two regions of northern Italy in 1997, 3rd International Symposium on PRRS and Aujeszky's disease, Ploufragan, France, 21-24 June 1999, Vet. Res. 31 (2000) 154-155. 